\title{
INSTITUTIONAL CONTEXT, CLASSROOM DISCOURSE AND CHILDREN'S THINKING: PEDAGOGY RE-EXAMINED
}

\author{
Gaysu R. Arvind \\ University of Delhi, Delhi, India
}

\begin{abstract}
At this time when credibility of public schooling in India is at low ebb, there is a need to analyze pedagogic discourse in terms of organization and structure of knowledge, school practices that mediate it, and the ways in which it is experienced by children. Building upon the works of Vygotsky, Bernstein and Bruner, a more encompassing account of pedagogic analysis can be realized that links sociological perspective of teaching practices with psychological understanding of learning processes. Drawing on findings from research in two different genres of pedagogic setting, the study provides a body of evidence that suggests strong role of the schooling context in framing social identities and life chances of learners; and its implications for reforming educational practice and policy.
\end{abstract}

KEY WORDS: Pedagogic Setting, Classroom Discourse, Cultural Practice

\author{
CONTEXTO INSTITUCIONAL, DISCURSO EM SALA DE AULA \\ E PENSAMENTO INFANTIL: PEDAGOGIARE-EXAMINADA
}

\begin{abstract}
RESUMO: Neste momento em que a credibilidade da educação publica na Índia se encontra enfraquecida, há uma necessidade de analisar o discurso pedagógico em termos de organização e estrutura do conhecimento, práticas escolares que o medeiam, e as formas como é experienciado pelas crianças. Construindo sobre os trabalhos de Vygotsky, Bernstein e Brumer, um relato mais abrangente da análise pedagógica pode ser realizado para conectar a perspectiva sociológica das práticas educativas com a compreensão psicológica dos processos de aprendizado. Abordando os achados da pesquisa realizada em dois diferentes gêneros de cenário pedagógico, o estudo proporciona um corpo de evidência que sugere um papel forte do contexto educacional na estruturação de identidades sociais e mudanças na vida dos estudantes; e suas implicações para a reforma das práticas e políticas educacionais.
\end{abstract}

PALAVRAS-CHAVE: Cenário pedagógico; discurso em sala de aula; prática cultural.

\section{The Context}

According to the Annual Status of Education Report, nearly 14 million Indian children are out of school, 52$55 \%$ of these out of school children are girls, and most children leave government primary schools without gaining basic skills in reading, writing and arithmetic (ASER, 2005 and 2006). Studies such as this tend to further stroke the simmering dissent with the dismal state of public education. The educational practitioners have responded umpteen times with an array of reformist measures ranging from enriching text-books to strengthening teacher training and development practices, however with little success. Part of the problem is that none of the policy makers and planners has ever considered articulating the relationship between the classroom discourse and the social, cultural, historical and institutional context in which it is constructed from a much wider holistic perspective. For instance, recently, at the recommendation of an apex national body, one set of school textbooks was substituted by another, but without changing the basic ways through which the children would intellectually and interpersonally realize the renewed curriculum. The intended educational gains are then likely to be limited.

Much of the same also holds true for educational research which generally takes the institutional context of school to be given. Studies of school effect have largely focused on generating simplistic account of school performance in terms of teacher or student-related variables, rather than figuring out the larger institutional modalities through which the teaching-learning processes are mediated. This reductionist stance has slighted the view that pedagogy should be construed as a form of socio-cultural activity that shapes an individual's identity, 
cognitive development, educational outcomes and life chances.

An over instrumental view of knowledge, increased bureaucratic regulation of school practices, and traditionally held folk assumptions about the mind's functioning and learning are some of the macro-level institutional ways that have influenced teaching-learning processes at the microlevel. Against this backdrop, this article seeks to understand how the cultural richness and diversity of the pedagogic setting, socialization histories of the various actors, and the cognitive tools available in a setup all interact at the inter-mental level to produce qualitatively different forms of intra-mental functioning. Pedagogy is conceptualized as an elaborate social activity through which cultural reproduction-production takes place.

The basic idea around which this paper is organized is that the pedagogic setting of a school is largely endogenous to the social and psychological context in which it is embedded. Different ways of social and institutional culture tend to produce distinctive patterns of school practices that hold the key to quality of teacherstudent interaction and educational outcome. Thus, by linking sociological perspectives of teaching practices with psychological understanding of learning and development processes, a more encompassing account of pedagogic analysis can be realized. A post-Vygotskian activity theory framework is well-suited for such an analysis as both social and psychological structures can be discussed with in a shared lexicon, and in a common web of meanings.

At this juncture, the paper has drawn upon Bernstein's work on sociology of pedagogy, Bruner's view on models of mind and learning, and Lave's perspective on curriculum organization to evolve an expanded activity theory framework to analyze the nature of primary classroom discourse as constructed and negotiated in different genres $^{1}$ of pedagogic settings: the state-regulated and the community-based school. Such an extended framework allows us to explore the educational implications of a generative model of pedagogic possibilities which connects a macro level of institutional analysis with the micro-level of interpersonal analysis. The study provides a body of evidence that is suggestive of strong relationship between organizational form and its realization at the level of learner.

\section{Socio-cultural Theory and Pedagogy: Evolving an Analytical Framework}

Socio-cultural theorizing is a multi-disciplinary perspective for understanding the relationship between human mental action, on the one hand, and the cultural, institutional and historical situation in which this action occurs on the other' (Wertsch et. al., 1995, p.11). It has its origin in the classical Hegelian philosophy, in the writings of Marx and Engels, and in the Soviet Russian Culturalhistorical psychology of Vygotsky, Leont'ev, and Luria. A corpus of informed researches in psychology, anthropology, education and other human sciences has revised and expanded the zone of socio-cultural theorizing by appropriating the various non-deterministic accounts of cognition and cultural practices. Amongst these are cultural-historical activity theory (Cole et. al., 1996), situated learning models (Lave, 1997) folk psychology and pedagogy (Bruner, 1996), distributed cognition approaches (Saloman, 1993), activity theory (Wertsch, 1995; Engestrom, 1999). They all share the view that the Vygotskain theory provides a valuable tool with which to examine and understand the processes of social formation of mind ${ }^{2}$. The emerging field of multifaceted search for connections and hybrids among divergent strands of socio-cultural research is referred to as the Post-Vygotskian studies (Daniels, 2001). The insights from these perspectives have meaningfully informed the pedagogic practices.

Ratner $(2005,1997)$ views that cultural practices and psychological processes are intertwined together, they depend on and sustain one another. "The relationship is like a spiral, where each passes into and builds on the other. Psychological phenomena are the subjective processes of practical cultural activity, and cultural activity is the practical objectified side of psychological phenomena that compose organized social life. However, activity is never divorced from psychological phenomena”. (Ratner,1997, p. 114). Thus, the individual and the cultural should be conceived of mutually formative elements of a single, interacting system. The focus is on those activities that eventually lead to the internalization of external human actions in the form of inner mental processes.

Activity theory is one such strand in socio-cultural theorizing that seeks to analyze the development of consciousness within the practical social activity settings. By dialectically linking the person and the social structures, the objectives is to gain a perspective on the local pattern of activity and the cultural specificities of thought and discourse. The activity theorists tend to foreground analysis of psychological processes within activity systems (Kozulin,2005).

Engerstrom (1999), the leading activity theorist has explicated three generations of activity theory which have developed in the six decades that have passed since Vygotsky's death. The essential characteristics of activity theory are: $\S$ One, child-in-activity-in-context is the unit of
study;

$\S \quad$ Two, 'contextual and oriented at understanding historically specific local practices, their objects, mediating artifacts, and social organization'; 
$\S \quad$ Three, 'based on a dialectical theory of knowledge and thinking, focused on the creative potential in human cognition'; and

$\S \quad$ Four, 'a developmental theory that seeks to explain and influence qualitative changes in human practices overtime' (Engestrom, 1999, p. 378).

It is fundamental to activity theory that the relation of individuals to every aspect of the world around them is essentially societal. Focus is on the societal nature of the human individual, as distinct from the social. Leont'ev elaborated upon human societality by stating that "in studying development of the child psyche, we must ....start by analyzing the development of the child's activity, as this activity is built up in the concrete conditions of its life (Leont'ev, 1981, p. 395). The societal nature of the individual human being, as engaged in cultural practices constitutes the concrete conditions of life. This approach necessitates shift in focus from either the individual or the larger social context to an activity system that allows an examination of the inter relationship between the individual and the cultural setting. With culturally organized human activities as the primary unit of analysis, social settings are not viewed as discretely circumscribed phenomena but instead occur as a part of interwoven social phenomena that occur in the moment and across time and space (Gutierrez et al., 1995). Engestrom (2008, 1999) has defined activity system as a social practice that includes the norms, values, division of labour, and goals of the community.

Daniels (2001) holds that the pedagogic possibilities of the socio-cultural and activity approach have remained under-theorized and under-researched. The distinct views about knowledge, modes of production of knowledge, ways of knowing, and child's position in the school practices constitute significant areas of contestation with in modern pedagogic theory. Ratner (1997) also notes that Vygotsky did not consider the ways in which real socio-institutional systems like schools bear on social formation of mind. The theory lacks the sociological perspective to analyze the structure of pedagogic discourse, the social relations of its production and the various modes of re-contextualizing it as a practice.

Bernstein's approach to the sociology of pedagogy provides one way of extending the power of socio-cultural and activity theory research. For Bernstein, the educational code of a school as scripted in its curriculum, pedagogic and evaluation practices acts as the form of organizational regulation. Social control is exercised through a framework of visible and invisible pedagogies. Visible pedagogies are bound by explicit sequencing rules that are rooted in social regulatory discourse. For instance, in a school context, the syllabus regulates the progression of a subject and the curriculum regulates the relationships between subjects and those selected as appropriate for given ages. In this framework, a learner is not constructed in terms of his 'natural' characteristics but in valence of scientifically validated capacities and ways of learning and behaving.

Visible pedagogies are realized through strongly classified and regulated spaces; essentially a book, a classroom and its material accompaniments, and other school practices. Child is subjected to a visible surveillance in terms of his "readiness" and "doing" abilities that are plotted in a normatively constructed evaluatory grid. This means that the potential space available to the child to learn is structured and hence gets limited.

As visible pedagogies are linked with means and forms of cultural reproduction, invisible pedagogies are linked with means and forms of indigenous knowledge production. This perspective is grounded in child's personal biography and learning is not regulated by explicit public control. In invisible pedagogies the sequencing rules are not explicit; they are implicit and are based upon theories of the child's inner development. Invisible pedagogic spaces are weakly controlled spaces in terms of persons, objects, and inter-personal socialization processes. This means that the potential space available to the child and the possibility of learning is very much greater. However, the potentiality of this open-plan living space as a pedagogic space to mediate learning is invisible to educational practitioners.

Bruner's (1996) account of institutional 'anthropology' of schooling brings out the situatedeness of education in all its complexity in the societal institutions. He holds that educational systems are themselves highly institutionalized structures that are largely informed by the traditionally held demographic beliefs about thinking and learning. "And like other institutions, education perpetuates itself and its practices" by establishing elite academics premised on such folk pedagogies (p. 32, emphasis original). Such a view of education is risky as it creates alienation, marginalization, defiance, and practical incompetence. A shift is needed to make education more responsive to needs, aspirations and self-esteem of the disadvantaged children.

Building up a case for situated view of mind as against the 'universal models', Bruner holds that education should be an empowering experience, it must help those growing up in a culture find an identity within that culture. Without it, they are bound to stumble in their effort. For realizing this cultural stance, the classroom practices should seek to construct pedagogic theories that regard children as active agents of their own learning. This entails building school cultures that operate as mutual communities of learners, engaged "jointly in solving problems with all contributing to the process of educating one another" (p.82). 
Lave and Wenger's (1999) perspective on $a$ learning curriculum and a teaching curriculum further compliments the socio-cultural perspective. A learning curriculum is essentially situated in a community. It cannot be disengaged from a community of practice that is a set of social relations among persons, activity, and lived world. "A Community of practice is an intrinsic condition for the existence of knowledge and participation in the community's cultural practice is an epistemological principle of learning" (p. 25). Thus, in a learning curriculum, field of learning resources is organized from the perspective of learners. A teaching curriculum, by contrast, structures resources for learning in didactic situations, regulates the meaning of what is learned, and in mediated by an extrinsic view of what knowing is about. Each type of curriculum defines possibilities for learning is terms of social structure of practice and power relations entailed in it.

To summarize, Bernstein, Bruner and Lave's pedagogic perspectives were appropriated to inform sociocultural approach as exemplified by activity theory of Engestrom. The emerging framework is a more powerful tool to examine the formative effects of larger institutional context and practices at the macro-level on face-to-face classroom interactions at the micro-level; and to consider possibilities for realizing education and human change.

\section{Study Design}

A meaningful way to realize the verifiability of this emergent framework is to inductively compare the construction of classroom discourse in two different genres of pedagogical settings. The term 'pedagogic setting' embodies a notion of setting as an orchestrated whole: "it is a practice that a teacher (or teachers), together with a particular group of learners, creates, enacts and experiences". Participants create, enact and experience - together and individually - learning purposes, knowledge and ways of knowing; rules of discourse; resources and artifacts; and the roles and relationships teachers and learners take place in a physically, politically and socially organized space (Leach and Moon, 1999, pp. 267). Pedagogic beliefs and practices are informed by a view of mind, of learning and learners, of the kind of knowledge that is valued and above all by the educational outcomes that are desired.

As an educational practitioner, I am closely associated with different genres of schooling system that exist in contemporary education scenario in India. They range from regimented government school system, on one hand to community based schooling provisions, on the other hand. Each school system reflects a complex interplay between its ideological underpinnings and pedagogic character in terms of textbooks, formalized curriculum, standardized examinations and assessment, the whole paraphernalia of a 'system' at work. In context of the present study, a state-regulated school and a community- based school are taken as two distinct genres of pedagogic settings that are inextricably linked to the social and institutional arrangements. The communitybased school is outside the regulatory structures and strictures of the state.

The larger objective was to understand the dynamics of pedagogic setting in influencing both the nature and quality of teaching; and ways in which children come to 'correctly position' themselves as particular sorts of learners in specific pedagogic and social locations. In the process, the study inadvertently ventured into judging the relative effectiveness of school and classroom practices, although this was not its prime concern. The idea was not to deride state school system but to recreate pedagogy by gaining meaningful insights into children's thinking and to challenge prevailing assumptions about the teaching-learning practices.

In this limited ethnographic study, data were collected at the levels of organization of classroom practices, pedagogical beliefs of teachers, and curriculum as experienced by learners. A transcript of the language of classroom transaction yielded an insight into the processes of communication, both verbal and non-verbal, through which meaning is conveyed and negotiated. The observations covered whole school events such as assemblies, children at play and teaching. The observation of teaching was the most sustained and detailed part of the study. Each lesson observation session was followed by an interview with the concerned teacher to probe into wider aspects of his/her thinking and pedagogic views. We recorded and collected examples of children's work. Thus collated observations were written into analytic vignettes which are interpretative accounts of children's positioning within specific school practices (Alexander, 2000).

The larger research questions guiding the study were: how teachers and students interact to construct various forms of pedagogic discourse; ways of communication that teachers and students develop within the pedagogic setting school and class; and how learning is socio-culturally bound to philosophical ethos of the school and teaching practices. Thus, the mainframe of the study was conceptualized to enable us to 'see' the design of the larger institutional culture in socially regulating a person (Daniels, 2001).

The study design takes into account the Brunerian view that pedagogy is never innocent; it is a medium that carries its own message and sub-text. Any choice of pedagogic practice implies a conception of learner and learning process (1999). From this standpoint, different pedagogical settings draw out different types of teaching- 
and-learning practices. With expansion of education, to facilitate the bureaucratic regulation, the mainstream 'pedagogic space' got increasingly scripted in terms of standardized curriculum, teaching and assessment practices. However, such pedagogical traditions based on 'banking model of education' are being continuously challenged by the view that child is not an empty vessel, but someone, able to reason, to make sense, both of one's and others' though processes through mutual dialogue. The child is then seen as an epistemologist as well as learner.

\section{Pedagogic Settings of School A: The Government Primary School}

School A is a typical government primary school that is located in a slum settlement colony in the northern outskirts of Delhi city. The pedagogic practices of this under-resourced school are bureaucratically regulated through centrally mandated curriculum packages, top down prescriptions for teaching methods and standardized tests that focus on low-level cognitive skills. There are elaborate administrative structures for overseeing and supervising the teachers' work in a hierarchically designed organizational culture. Teachers work in isolation from one another, stamping students with the centrally produced lesson plans. Students, too, passively listen to lectures, memorize facts and algorithms and stagger towards the desirable achievement level.

The social identity of children attending School A is quite obvious, they are children of landless farmers, casual labourers, artisans, and other dispossessed groups who have been unwittingly subsumed in the industrial economic order of the large metropolises. Largely, they are first generation learners. For slum-based community, material impoverishment, social dislocation, exclusion from society's strategic resources, in particular the functional school is an inscribed way of life.

The following episodes yield a meaningful insight into pedagogic character of school that is largely assumed to be the function of institutional dynamics and local socioeconomic context in which the school is located. School culture can be construed from what is enacted in the classrooms, playground, from the blackboard to what goes on inside children's minds.

\section{Math Classroom}

The following transcript of a primary classroom discourse typifies a pattern of teaching, social positioning of a learner and pedagogic space accorded to her way of constructing knowledge.
The Children are seated on floor, one behind the other, facing the black board.

8:30 Teacher announces the topic - 'Statement Problems' and writes this on the blackboard. She poses some basic questions related to the topic that are voluntarily answered by the willing students.

8:40 She explains the method to students and solves an example problem on the blackboard.

Cost of 5 pencils $=$ Rs. $15 \quad$ Cost of 1 pencil $=15 / 5$ $=$ Rs. 3

Cost of 8 pencils $=3 \times 8=$ Rs. 24

8:45 Teacher asks, "Have you understood 'the method' of solving statement problems"? Some reply affirmatively, some are disquieted, and others are not concerned. No major clarification is sought by the students.

8:47 Teacher dictates four 'statement problem' sums that are to be solved by students.

8:52-9:04 Students work independently, trying to solve questions in their exercise book by applying 'the teacher's method'_- first step is division, and next is multiplication, whilst the teacher completes the official routine work. A doubt or query raised by the students in a muffled voice is ignored by the teacher. Any attempt to discuss the problem with the fellow student is either met with a stern glance or is being punitively directed 'not to cheat'.

9:05 School bell rings. Teacher instructs students to finish the exercise given on page 160 of the math's textbook ${ }^{3}$.

Many such accounts of regulated classroom discourse were documented. These accounts reveal that the major aim was to didactically convey a mathematical concept and let pupil practice as much as possible. Drill and memorization were the mainstay strategies to enable students acquire procedures - recipes for step-by-step solutions to mathematical problems - without understanding their conceptual rationale. For Bruner (1996), didactic teaching is based on the notion that pupils should be presented with propositional facts, principles, and rules of action which are to be learned, memorized, and then applied. Knowledge is largely a factual matter that is simply to be 'listened to' or 'absorbed'. The following instance exemplifies how the sheer inertness of the teaching method got carried over to children's thinking:

One of the given questions was, "If 6 men can dig a field in 12 hours, how much time would it take for 4 men to do the same job". Invariably, all the students 
arrived at the answer by first dividing and then multiplying:

6 men can dig field in $=12 \mathrm{hrs}$.

1 man can dig it in $=12 / 6=2 \mathrm{hrs}$.

4 men can dig field in $=2 \times 4=8 \mathrm{hrs}$. (The correct answer is 18 hrs.)

In this teaching scenario, the dominant pedagogical belief is that the learner's mind is passive, a tabula rasa, and a receptacle waiting to be filled. The possibility of regarding child as an active constructor of knowledge does not exist. Teaching is largely a one-way activity, not a co-construction of knowledge by teacher and students together as they engage in joint activities, which are negotiated rather than imposed. In this folk pedagogical framework, child's academic failure is falsely attributed to her back of mental abilities or low intelligence and the institutional arrangements go scot-free.

\section{Environmental Studies Classroom}

Teacher : Teacher announces the topic - 'things needed by a plant to be alive' and writes this on the blackboard. She asks for probable examples.

Students : : Air, water, oxygen, chlorophyll, leaves, sun, soil, food, roots.

Teacher : $\quad$ Air, Water and Sunlight are the essential things needed by a plant to keep it alive. Write this in your notebook. Rephrasing a textbook activity, teacher asks, "Suppose you have two potted plants A and B. Plant A is kept inside a room and Plant B is kept under the sun is an open field. What would you observe after a week?"

Students : Over half of the class spontaneously replied that the Plant B kept under the sun would die.

Teacher : : Dumb children! Just now I told you that sun is necessary for survival of the plant. Plant A kept inside the room would die. Look at the textbook at page $53^{4}$. Draw the diagram of the activity in your notebook.

Students : Quietly started drawing the diagram. No further clarification sought.

From the above episode it emerges that the teacher did not make any effort to understand why children answered that the plant kept in the sun would die. On probing by the author, children articulated their perspective: in hot summer of Delhi, it is largely the outdoor plants that get burnt and wilted and eventually die. The same also holds for human beings, the sun stroke can be fatal. On basis of their personal experiences, they observed more of life-sapping characteristic of sunlight than the life-supporting. However, there was no legitimate space to count in children's thinking in this text-bookish approach to knowledge and teaching. Further, there was no attempt to clarify the propositional mis-construction that it is not the sun but the excessive transpiration or water loss in summer that results in wilting and burning of leaves.

The episode also brings out the ubiquity of 'recitation script' as the dominant pedagogic practice. The recitation script consists of a series of unrelated teacher questions that require convergent factual answers and students display of known information. It seeks predictable, correct answers. Rarely, in such a pedagogic practice, are teacher questions responsive to student production and assist students to develop more complete or elaborate ideas. Rote learning and immediate responses are emphasized (Tharp and Gallimore, 1988). The script itself is not questioned. That is, the tacitly assumed traditions and/or the given official rules of engagement with the problem are not challenged.

It can be inferred from these pedagogic accounts that, educational code of the government primary school approximates the Bernstein's view that in strong framework of visible pedagogies, there is a marked insulation between forms of production of knowledge and psychological ways of constructing it. In such an institutionally structured framework, hierarchy is explicit; space, time and contents are regulated; and the strong boundaries are maintained to exercise social power. "The child, abstracted from her cultural context has no potential space and power to bring her thinking processes into the schooled discourse" (1997, p.67).

The government schools are bureaucratically organized into chains of authority through which supervisory responsibility is exercised. In this organizational matrix, teachers themselves are meekly positioned. The teachers are administratively controlled through paternalistic structures that further perpetuate infantilization and unprofessionalism in them. The school context does not provide opportunities for professional growth and collaborative work culture. Teacher training is largely a bureaucratic ritual that is largely geared to enriching subject matter rather than being alive to pedagogical issues and concerns. In this educational culture - each member of the supervisory chain tries to control, not support, the performance of the next. The administrative practice of regulating teachers is then organically linked to the practice of scripting the classroom discourse in a conventionally directed recitation mode.

At this juncture, three distinct sets of social and institutional realities in which children are embedded can be explicated: one, the larger socio-economically 
disadvantaged familial and societal context; two, child attending an under-resourced government school that is located in a spatially excluded area, a slum; and three, child's passive positioning in classroom discourse that is regulated by a strong framework of visible pedagogies. The identity of children emerging from their asymmetrical positioning in this dialectically interacting socially and institutionally bound pedagogical context is not difficult to discern: a low self-concept towards self and school; and limited educational and life chances. The drop-out rate is considerable. Most of the school drop-out children take to rag picking and garbage sorting activities.

Abdul, a migrant from West Bengal and an early school drop-out regards his schooling experiences to be as dangerous as his job of garbage sorting. A cultural discontinuity between his lived reality and schooling practices in terms of the language of the classroom discourse, teachers perceptions, ethnic name calling, and lack of proficiency in Hindi, the second language for him but the medium of school instruction were the key factors in disengaging from school. Rag picking emerged as a logical life option. From Bruner's perspective, the traditionally held reproductive function of the school in shaping of particular identities and histories by marginalizing specific cultural narratives and resources is affirmed.

\section{Pedagogic Account of School B: Samudayik Pathshala}

Samudayik Pathshala, as the name signifies is a community school in Devron Ki Dhani, a small habitation in Umrein Block of Alwar District in Rajasthan, some hundred miles north of Delhi. The school emerged in response to the need articulated by the local community, the major stakeholder and got pedagogically realized by Bodh, the local NGO. In this collaborative effort, land, human labour and other infrastructural resources were provided by the community; and the NGO supported the community initiative by way of institutionalizing its pedagogic approach, practices and resources. Marginal farmers, petty artisans, landless labourers and the Nut community, a peripatetic group of performing artists constitute the social fabric of the habitation.

The school is envisioned to be an organic extension of the school. The classroom is seen as an evolving learning space, in which mobility and movement is based on children's abilities and quest for learning. The spaces are not clearly demarcated, as learning experiences take place in multiplicity of contexts, which could be in a play field, under a tree, or on a chabootra - a village platform which is an extension of the community's living space. The entire cohort of children assigned to a particular class are sub-divided into flexible sub-groups for facilitating learning the thematically organized curricular areas at their own pace. The curricular experiences are linked to children's immediate social and cultural context. Children's learning is support by a continuous process of monitoring and feedback.

To summarize, the educational edifice of the community school is premised on the pedagogic belief that effective teaching requires knowledge of students, their experiences, and the ways in which they learn. For realizing this approach, an elaborate system of teacher support is in place. Weekly review meetings, monthly workshops, yearly training programmes, peer-tutoring and mentoring are some of the organizational ways of supporting teachers.

\section{Book Reading Activity: Developing Literacy Processes in Natural Settings}

Just as language learning begins long before the child utters the first word, literacy development begins prior to formal reading instruction. It is now widely held that listening, speaking, reading and writing abilities develop concurrently and inter-relatedly, rather than sequentially. Literacy emerges in the sense that a child gradually develops as a thinker, reader and writer in everyday activity settings. In the community school, this emergent view of literacy was further expanded by seizing a literacy event such as 'book reading' as a context of generating and weaving concepts - both everyday and schooled into existing cognitive structures.

The defining feature of the 'book reading' activity is to read the text and talk together about it. The text may be a storybook, a news paper clipping, or students' or teachers' own writing. The activity task is distinctively designed to build a collaborative discourse that links children's 'scientific concepts' - the schooled concepts with 'spontaneous concepts' - those concepts that were acquired by the child outside the context in which explicit instruction was in place. The role of the teacher in this interactive - discussion is to draw out the children's emergent understanding of the text, to realize it in ways that assist comprehension beyond the levels students can achieve alone, and thereby develop increasing competency in schooled discourse.

The following instance exemplifies how a 'book reading' task emerged as a collaborative activity to construct a more dynamic from of pedagogic discourse in which active learners bring together multiple sources of information including their own previous informal knowledge. A mix of students of class three and four students participated in 'book reading' task. The story, 'Friendship', voluntarily read by a class-three student 
generated a spectrum of thinking processes ranging from simple language acquisition to conceptually advanced procedural knowledge.

\section{The Story: The friends}

Chunmun, a sparrow used to nest admits the branches of an old banyan tree. A black snake had also burrowed at the base of the banyan tree. The snake used to eat eggs and young ones of the sparrow. The saddened Chunmun requested Chilbil, an eagle to kill the snake. One day, the eagle pounced upon the snake and killed it by striking it against a rocky surface. Chunmun and Chilbil became friends forever.

After the 'book reading', through interactive discussions, children were encouraged to search meaning and formulate perspective on the text. Digression, incomplete utterances, and differing viewpoints were the accepted norm. Some of the atypical children responses that transcended the disciplinary boundaries were:

Child \# $1 \quad$ : Snake is nocturnal and eagle
is diurnal, I am wondering what could have been the
opportune time for eagle to strike?

Child \# 2 : $\quad$ Snakes are good as they eat rats. Rats damage the standing crop and stored food grains.

Child \# $3 \quad$ : $\quad$ If snakes are killed, population of rats would increase and this is not good for our crops.

Child \# $4 \quad$ : $\quad$ Snake, eagle and sparrow lay eggs whilst rats have young ones like cats, dogs and humans.

Child \# 5 : $\quad$ The trees give out oxygen, the good air and takes in carbon dioxide, the bad air.

The other responses were on medicinal and religious value of banyan tree, difference in beak structure and nesting habits of eagle and sparrow, and on value of friendship. The sheer ingenuity, fluidity, and diversity in responses gave an insight into quality of children's thinking processes, indeed the high-ordered cognitive acts by any measure of intelligence. The teacher acted as an anchor to weave together every day and schooled understanding to enhance the dialectical development of concepts. For instance, children's understanding of negative correlation between population of snakes and rats was used to promote the concept of food chain. Using a story as a cue to generate a wide-ranging discussion emerged as a valuable pedagogic practice. And the story book in contrast to the school textbook allowed children to express their thinking processes in a freewheeling way rather than in officially coded explicit way.
Regaining of 'Voice' by Arun: Case Study of a Mute Boy

'Goonga' - literally meaning 'mute', was four years old when an accident impaired his ability to linguistically express himself. The speech disorder eroded the young child's self-esteem and he started socially distancing himself. This further intensified the impairment.

Against this backdrop, Goonga was sent to the community school. To meaningfully integrate him into school processes, teachers encouraged him to actively participate in activities like morning assembly, sports, field trips, singing and book reading. A continuous engagement with the activities enabled Goonga to dislodge his previously held psychological structures that were barriers to literacy acquisition; and created possibilities to experience a new personal sense and meaning. Learning to read, write and spell emerged as the powerful ways to realize this goal directed conscious behavior. Responding to an enabling school culture, the boy rapidly gained school competencies. The school teachers rechristened Goonga as Arun - the charioteer of the sun-god. As of now, Arun is shaping as a confident boy who loves to play, read and debate. He wants to become a teacher. The family is simply marveled at the transformatory potential of education. A field visit after a year affirmed the stability of gains.

From the perspective of socio-cultural theorizing, school's pedagogical practices provided a therapeutic context to Arun to reconstruct his identity by overcoming his disability in a naturalized fashion. The speech disorder was addressed by drawing out the child into other meaningful activities that not only compensated for the deficient articulation skills but also provided the platform to anchor literacy skills. The study established the importance of larger socio-cultural context at macro level in shaping psychological processes at micro level.

It can be inferred from these pedagogic accounts that, educational code of the community school approximates the Bernstein's view that "the weak classification and frames of the invisible pedagogy emphasis the importance of ways of knowing, of constructing problems" (Bernstein, 1997, p. 72; emphasis original). The invisible pedagogy potentially makes possible the inclusion of children's everyday experiences and culture in building the classroom discourse. The teacher organizes a collaborative context, with in which child apparently has wider powers over how she structures her activities and regulates her own pedagogical positioning and social relationships.

The agentive view of mind regards learner to be proactive, problem-oriented, constructional, directed to ends. 'For the agentive mind is not only active in nature, but it seeks out dialogue and discourse with other active minds'. And it is through this dialogic culture, discursive process that we come to know the other and her points 
of view, her stories. Agency and collaboration are complimentary processes (Bruner, 1996, p. 93).

The school culture embodies the pedagogic belief that teacher development is a continuous process and a child's failure to learn is a problem to be solved by evolving appropriate teaching practices. In community school, teachers are professionally supported through a wide range of reflective practices in which teachers monitor, evaluate and revise their own practices continuously. The reflective activity is enhanced through collaboration and dialogue with fellow educational practitioners. In weekly held review meetings, experiences are shared, language and concepts for analyzing practice are refined and innovative ways of influencing educational outcomes are encouraged. The author was the participant observer to one such review meeting: in a rigorously planned meeting, subjective impressions and understandings are deconstructed by carefully gathered classroom evidences and insights collated from an analytical reading of the educational texts. The purpose of the whole activity was to support a shift from routine actions rooted in traditional thinking to reflective practice stemming from professional thinking. The pedagogic posturing then measures up to Pollard's position on reflective teaching (2006).

The educational gains of such a supportive pedagogic context are encouraging: most of the children are in school, there is regularity of student attendance with a minimal drop-out, and incidents of children migrating with their parents in search of livelihood have come down. There is a visible change in the mind-set of parents as they have started articulating their concerns about schooling of their children at the village-level public forums. They had begun to envision career options for their children in their limited lived realities.

Rehana, a class VII student of the government secondary school in Doba, Umrein is an alumnus of the community school. Fazlu, her father and a tailor by profession takes pride in announcing that Rehana is the first girl in whole of the local Muslim community to attend a high school. In a recently held school function, she was adjudged the best student for consistently high performance in academics and co-curricular activities. As Bruner would have concurred that with the 'cultural toolkit' provided by the school, Rehana is successfully treading the path of becoming a teacher. The school culture nurtured her cognitive potentialities and empowered her with a toolkit to realize her vision. With Rehana's accomplishments, the entire local minority community has started believing in the possibility of realizing better life options for their girl child through education.

\section{Discussion}

The study establishes schooling as an elaborate form of institutionalized socio-cultural activity in which specific forms of pedagogic discourse are constructed. A pedagogic practice as informed by a view of mind acts as a cultural artefact or psychological tool for mediating teaching-learning processes. Thus, school's educational code tends to get regulated by tacit pedagogic beliefs and assumptions that are inhered in the institutional arrangements in which it is located. A radically extended Vygotskian framework provides a theoretical tool to deconstruct the ways of production of such embedded discourses in activities structured through specifiable relations of power and control within social and institutional spaces.

From the perspective of Vygotsky - Bernsteinan framework of pedagogy, two schools, state-regulated and community-based signify different ways of structuring children's consciousness, learning experiences and future life options (Table 1). School A, the government primary school is regulated by 'officially' held pedagogic view that teaching is a practice of formatting children's thinking in highly compartmentalized school subjects that emphasize static state of propositional knowledge. Children have no control over their learning processes and space. Recitation, drill and modeling are the forms of visible pedagogies that are largely located in universally sequenced way of learning and development. Such pedagogic approaches tend to abstract the child's personal biography and local context from her cultural biography and institutional context (Bernstein, 1997). The pedagogic reality of a formal classroom mirrored the hierarchical cultural and controlling practices of the mainstream education system.

On the other hand, School B, the community school is supported by reflective pedagogic practices that emphasize the dynamic way of knowing and constructing knowledge through thematically organized curricular experiences. Inter-subjectivity, collaborative learning, reciprocal teaching and meta-cognitive teaching are instances of the invisible pedagogies that view teaching as a practice of enabling children to reflect upon, negotiate and manage their own thinking and learning space. Such pedagogic approaches provide for an alternative Vygotskian view of human agency that holds that "the social dimension of consciousness is primary in time and in fact. The individual dimension of consciousness is derivative and secondary" (Vygotsky, 1978, p.30). 
Table 1: Framework for articulation of social and institutional embeddedness of pedagogic discourse

\begin{tabular}{|c|c|c|}
\hline $\begin{array}{c}\text { Genres of Pedagogic } \\
\text { Setting }\end{array}$ & $\begin{array}{c}\text { School A } \\
\text { The Govern ment Primary School }\end{array}$ & $\begin{array}{c}\text { School B } \\
\text { The Community School }\end{array}$ \\
\hline $\begin{array}{l}\text { I. Notion of School and } \\
\text { organization of its } \\
\text { pedagogic space }\end{array}$ & $\begin{array}{l}\text { Fixed, stand-alone, rule-bound, } \\
\text { regulated by state directed } \\
\text { practices, alienated from larger } \\
\text { social realities, 'token' } \\
\text { community participation in } \\
\text { school } \\
\text { A very small bound space; } \\
\text { limited material base, usually a } \\
\text { table, a chair or a book } \\
\text { Child is regulated by strongly } \\
\text { classified space. }\end{array}$ & $\begin{array}{l}\text { Evolving, expansive notion } \\
\text { of school as an organic } \\
\text { extension of community } \\
\text { - } \quad \text { Large material base, usually } \\
\text { extending to exteriors of } \\
\text { school; no strong boundaries } \\
\text { The potential space available to } \\
\text { child to negotiate is much } \\
\text { greater. }\end{array}$ \\
\hline II. Pedagogic Practices & $\begin{array}{l}\text { - Visible pedagogies, strong } \\
\text { classification and strong framing } \\
\text { for regulating the pedagogic } \\
\text { discourse } \\
\text { Explicit rules to sequence } \\
\text { curriculum in highly structured } \\
\text { disciplinary subjects, largely a } \\
\text { teaching curriculum } \\
\text { Focus on instrumental ways of } \\
\text { transmission and acquisition of } \\
\text { knowledge } \\
\text { Recitation, modeling, drill and } \\
\text { other didactic pedago gic } \\
\text { practices } \\
\text { Pedagogic beliefs and assumptions } \\
\text { are grounded in universally } \\
\text { sequenced, innate view of mind and } \\
\text { learning. }\end{array}$ & 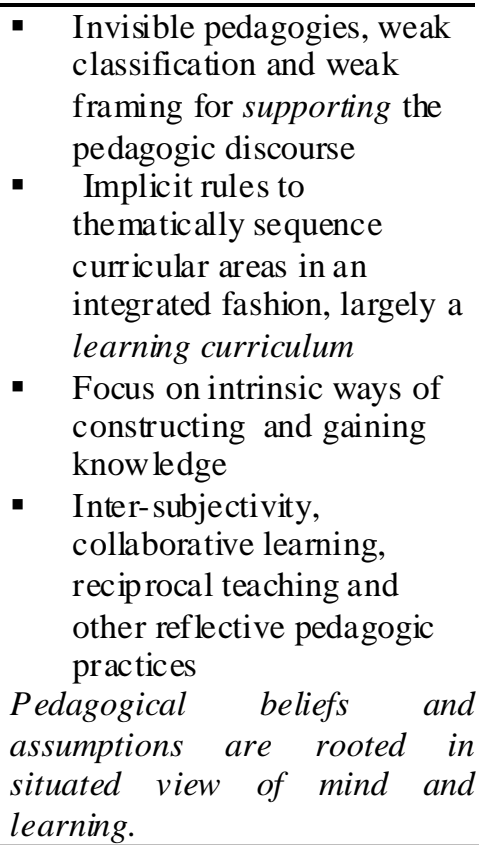 \\
\hline $\begin{array}{l}\text { III. Teacher training and } \\
\text { development }\end{array}$ & $\begin{array}{l}\text { - Teacher training is a routinized } \\
\text { activity that is largely directed } \\
\text { by institutional ways and beliefs } \\
\text { of maximizing learning gains } \\
\text { A significant chunk of the } \\
\text { training programme focuses on } \\
\text { enriching subject matter rather } \\
\text { than on pedagogical ways of } \\
\text { conveying it } \\
\text { Teacher performance is graded } \\
\text { on bureaucratic criterion-scale } \\
\text { Focus is on teacher control and } \\
\text { regulation }\end{array}$ & $\begin{array}{l}\text { - Professional development of } \\
\text { teachers is enhanced } \\
\text { through reflective practices } \\
\text { that use classroom research } \\
\text { as a means of improving } \\
\text { educational practices } \\
\text { Teachers continuously } \\
\text { monitor, evaluate and revise } \\
\text { their own practices through } \\
\text { collegial and reflective } \\
\text { discussions } \\
\text { Thrust is to support and assist } \\
\text { teachers }\end{array}$ \\
\hline $\begin{array}{l}\text { IV. Ideological and } \\
\text { Theoretical } \\
\text { Underpinnings }\end{array}$ & $\begin{array}{l}\text { Behaviorism, Cognitive scientism, } \\
\text { neo-liberalism and other positivist } \\
\text { perspectives }\end{array}$ & $\begin{array}{l}\text { Contextualism, social } \\
\text { constructivism, cultural - } \\
\text { historical situa tedness, and other } \\
\text { dialectical perspectives }\end{array}$ \\
\hline
\end{tabular}

Source: Theoretical positions of Bernstein, Bruner, and Lave; and Empirical evidences of classroom account 
Summing up, different school cultures articulated different pedagogic meanings and life chances in spite of sharing the same socio-economic location and context. The pedagogic setting of the school made all the difference. Table 1 signifies the ways of renewing pedagogy as a socio-cultural practice. It affirms the culturalist view that the school can never be considered as culturally 'free standing'. "What it teaches, what modes of thought and what 'speech registers' it actually cultivates in its pupils cannot be isolated from how the school is situated in the live and culture of its students". For a school's curriculum is not only about 'subjects', it is about how most students experience it, and what meaning they make of it (Bruner, 1996, p. 28, emphasis original). The shift in educational code from visible to invisible pedagogies holds the prospects for reforming school practices for empowering disadvantaged children for whom even moving from home to school is itself an act of cultural change. The pedagogic setting should build self-esteem and identity of learners, developing their sense of what they believe or indeed hope themselves to be capable of. It would then embody the possibility of evolving critical and transformative spaces both in and out of schools that enlarge the terrains of human capacities for realizing social justice and entitlement (Giroux, 1988).

\section{Concluding Observations: Recreating Pedagogy as a Socio-Cultural Practice}

The objective of the study was not to decry the state of public school system but to recreate pedagogy by gaining insights into children's thinking and to challenge prevailing assumptions about the teaching-learning practices. The idea was to understand the dynamics of pedagogical context that makes education as an empowering experience for a marginalized child for whom school is the only potential site to break the vicious circle of poverty, social denigration and ascribed life options. The study brings out ways of reforming educational practices:

(i) Seeing children as active agents of their learning: The educational code of the school should hold the belief that children are not empty vessels but are capable of reasoning and making sense of their own thinking processes through reflective practices of collaboration and negotiation-by becoming 'meta' as in the Brunerian conceptualization of pedagogy. The child's mind is to be seen as proactive, problem oriented and constructional in nature; she is an epistemologist as well as a learner. This view of education is largely dialectical, more concerned with interpretation and understanding than with the passive memorization of factual knowledge. The pedagogic challenge is to create settings that intellectually engage and motivate learners in a meaningful way.

(ii)Linking 'owned knowledge' with 'school knowledge': The relationship between school and non-school knowledge is central to issue of power and control within the classroom context. By legitimizing and organically linking children's everyday understanding of contextual knowledge with formal concepts, the school should create a pedagogic possibility of positioning its bearer as an active subject, able to use her owned knowledge in a dynamic way. From Bernstein's perspective, weakening of boundaries has expanded the potential space available to children to learn. The pedagogical challenge is to recognize and nurture children's knowledge as constructed in a spectrum of varying cultural contexts and meaningfully weave it in classroom discourse.

(iii) Ensuring conceptual continuity between curriculum as enacted and curriculum as experienced by learners: The study suggested that when textbook and learning is institutionally regulated, as in math classroom, pedagogic practice conflates the sequencing of curriculum and learning process. A sequence missed or misunderstood then becomes learning rather than teaching failure. The challenge is to create a setting in which participation of every child is ensured; and teacher is empowered to take 'appropriate pedagogic decisions' as necessitated by specific learning dynamics of the class rather than as stipulated in syllabus. The context specific planning of curriculum and designing of learning activities marks the beginning of pedagogy.

(iv)Teachers as community of reflective practitioners: A school system should professionally support its teachers through a wide range of reflective practices in which teachers monitor, evaluate and revise their own practices continuously. This perspective is premised on the belief that school is a site and frame for learning and critical reflection. The reflective process is enhanced through collaboration and open dialogue with fellow educational practitioners. The school should create review forums for enabling teachers to share and analyze their school experiences in a collaborative mode; to deconstruct their subjective impressions and understandings by examining systematically gathered classroom evidences; and to jointly evolve innovative ways to positively influence schooling outcomes. The purpose of this reflective activity would be to support a shift from routine in-service teacher training programmes rooted in traditional view of teachinglearning to capacitate teachers to build a more informed position on school practices. 
These are some of the ways of renewing pedagogy that signify a shift from the instrumentalization of teaching methodology towards an understanding of dialectic interplay of complex elements involved in creating effective communities of reflective learners and practitioners. Moving away from the conventional dichotomies of 'good' and 'bad' practices, the focus is to intellectualize pedagogy as a measure of personal, educational, and social mobility. This shift is warranted as in the emerging neo-liberal discourse, the institutional arrangements of the state are increasingly geared towards attaining quantifiable delivery targets and outcomes - not the ways of creating and gaining knowledge. Bernstein's sociology of pedagogy allowed us to contest the overinstrumental view of education as acquisition and transmission of knowledge as realized through insulation between disciplinary fields, and insulation between educational and everyday knowledge. A fundamental "shift from an epistemological form of accountability to an administrative form of accountability" is to be resisted as this weakens the education and life chances of the marginalized children by systemically undermining their contextual knowledge, ability, and consciousness (Young, 2008, p. 96-97, emphasis original).

Bruner and Bernstein's work as situated in the larger socio-cultural perspective provide an alternative framework to conceptualize an expansive notion of education that is pedagogically responsive to diverse learners by supporting their identity, learning, and world view. 'School Culture' is also conceptualized as that of equipping a child with cultural toolkit to take on the emerging socio-economic realities in a constructive way (Bruner, 2006). Teachers are equal partners in this renewal process. The educational possibilities of such an expanded framework await a full consideration within the sociocultural and activity discourse.

\section{Notes}

${ }^{1}$ The notion of genre is used as sophisticated analytical tool to understand the consequences of the pedagogic practices on children's thinking and educational outcomes. As Russell explicated that "a genre is ordinarily best analyzed at the level of operation, a typified use of some meditational means, to carry out a typified action, an action which in turn furthers the motive and acts upon the object of some collective activity system" (Russell, 1997, p.6). In the present study, two school types typify the genres of pedagogic setting. Gordon Wells (1999) and Harry Daniels (2001) have used the notion of genre in their study of socio-cultural practice and pedagogy.

${ }^{2}$ For detailed understanding of radical extension of the Vygotskian perspective, refer to the classical texts by: Yrjo Engestrom et. al. (1999) - Perspective an Activity Theory; Alex Kozulin et. al. (2003) - Vygotsky's Educational Theory in Cultural Context; Michael Cole et. al. (1997) - Mind, Culture and Activity; James V. Wertsch et. al. (1995) - Socio-cultural Studies of Mind.
${ }^{3}$ Maths Textbooks of Class Four; SCERT: Delhi Textbook Bureau.

${ }^{4}$ Environmental Studies Textbook of Class Five; SCERT: Delhi Textbook Bureau.

\section{References}

Alexander, Robin. (2000). Culture and Pedagogy. Oxford: Blackwell Publishers.

Apple, Michael W. (1995). Education and Power. New York: Routledge, 1993.

Arvind, G. (2007). Culture, Artifacts and Mediated Learning in S. Manikutty (ed.) Intercultural Communication Competence: Learning, Teaching and Research in a Borderless World. New Delhi : Macmillan.

Annual Status of Education Report (ASER). (2006). Mumbai: Pratham Resource Center.

Bernstein, B. (1997). Class and pedagogies: Visible and invisible. In A.H. Halsey et al (eds.), Education: Culture, Economy and Society. Oxford: Oxford University Press.

Bernstein,B. (1996). Pedagogy, Symbolic Control and Ideology:Theory, Research and Critique. London:Taylor and Francis.

Bernstein, B. (1999). 'Vertical and horizontal discourse: an essay. British Journal of Sociology of Education, 20, 2:157-73.

Bourdieu, P. 1997. Cultural reproduction and social reproduction. In R. Brown (ed.), Knowledge, Education, and Cultural Change, pp. 71-112. London: Tavistock Publications.

Bruner, J. (2006). In Search of Pedagogy: Vol. I and II. London: Routledge.

Bruner, J. (1996). The Culture of Education. Cambridge: Harvard University Press.

Bruner, J. S.(1987). Prologue to the English edition. In L. S. Vygotsky. Collected Works (Vol. 1, pp. 1-16) (R. Rieber \& A. Carton, eds.; Minick, N., transl.). New York: Plenum.

Chaiklin, S. and Lave, J. (1996). Understanding Practise : Perspectives on Activity and Context. NY: Cambridge Univ. Press.

Cole, M. (1996). Cultural Psychology. Cambridge: Harvard Univ. Press.

Cole, M. (1999). Cultural Psychology : Some general principles and a concrete example.

In Y. Engestrom, R. Miettinen, and R. Punama Ki (eds.), Perspectives on Activity Theory (pp. 87-106). Cambridge: Cambridge University Press.

Cole, M., Engestrom, Y., and Vasquez, O. (1997). Mind, Culture, and Activity. Cambridge, England : Cambridge University Press.

D'Andrade, R. (1995). The Development of Cognitive Anthropology. NY: Cambridge Univ. Press.

Daniels, H. (2001). Vygotsky and Pedagogy. London: Routledge.

Daniels, H., Cole, M., and Wertsch, J. (Eds). 2007. Cambridge Companion to Vygotsky. New York: Cambridge University Press.

Daniels, H., Leadbetter, J., Soares, A., and McNab, N. (2007) Learning in and for cross-school working, Oxford Review of Education Vol. 33, No. 2, , pp. 125-142.

Davydov, V.V. and Zinchenko, V.P. (1993). Vygotsky's contribution to the development of psychology. In H. Daniels (ed.), Charting the Agenda : Educational Activity after Vygotsky. London: Routledge.

Engerstrom, Y. (1987). Learning by expending: An activitytheorectical approach to developmental research. Helsinki: Orienta - Konsultit.

Engerstrom, Y. (1999). 'Innovative learning in work teams:analyzing 
cycles of knowledge creation in practice', in Y.Engestrom et al (eds) Perspectives on Activity Theory. Cambridge:Cambridge University Press.

Engestrom, Y. (2008). From Teams to Knots: Studies of Collaboration and Learning at Work. Cambridge: Cambridge University Press.

Giroux, H. (1988). Critical theory and the politics of culture and voice: Rethinking the discourse of educational research. In R. Sherman and R. Webb (Eds.) Qualitative research in education: Focus and methods (pp. 190-210). New York: Falmer.

Gutierrez, K. D. and Stone, L.D. (2000). Synchronic and diachronic dimensions of social practice: An emerging methodology for cultural -historical perspectives on literacy learning. In C. D. Lee and P. Smagorinsky (eds.), Vygotskian persectives on literacy research. Cambridge: Cambridge Univ. Press.

Kozulin, A. , Gindis, B., Ageyev, v. and Miller, S. (eds.) (2003). Vygotsky's educational theory in cultural context. Cambridge: Cambridge Univ. Press.

Kozulin, A. (2005). The concept of activity in Soviet Psychology: Vygotsky, his disciples and critics. In Harry Daniels (Ed.), An introduction to Vygotsky (pp. 101-124). London: Routledge.

Lave, J. (1997). The culture of acquisition and the practice of understanding. In David Kirshner and James A. Whitson (eds.), Situated Cognition : Social, Semiotic and Psychological Perspective (pp. 17 - 36). London: LEA.

Lave, Jean and Wenger, E. (1997). Learning and pedagogy in communities of practice. In Leach and Moon (eds), Learners and Pedagogy. London: Paul Chapman Publishing.

Leach, J. and Moon, B. 1999. Learners and Pedagogy. London : Paul Chapman Publishing.

Lee, C. D. and Smagorinsky, P. (2000). Vygotskian Perspectives on Literacy Research : Constructing Meaning through Collaborative Inquiry. Cambridge, UK : Cambridge University Press.

Leont'ev, A. V. (1997). On Vygotsky's creative development. In Rieber, R. W. and Wollock,

J. (eds). The Collected Works of L. S. Vygotsky: Problems of the Theory and History of Psychology, Volume III (pp. 9-49). New York : Plenum Press.

Moll, L. C. (2000). Inspired by Vygotsky: Ethnographic experiments in education. In Carol D. Lee and Peter Smagorinsky, Vygotskian Perspectives on Literacy Research : Constructing Meaning through Collaborative Inquiry (pp. 256 - 268). Cambridge, UK : Cambridge University Press.

Pollard, A. (2006). Reflective Teaching: Evidence-informed Professional Practice. South Asian Edition. London : Continuum.

Portes, P.R. and Vedeboncoeur, J.A. (2003). Mediation in cognitive socialization: The influence of socio-economic status. In Alex Kozulin et al (eds.), Vygotsky's Educational Theory in Cultural Context. Cambridge: Cambridge Univ. Press.

Ratner, C. (1997). Cultural Psychology and Qualitative Methodology: Theoretical and Empirical Considerations. New York : Plenum Press.

Ratner, C. (2006). Cultural Psychology: A Perspective on Psychological Functioning and Social Reform. Mahwah, NJ: Erlbaum.

Ratner, C. (2007). Qualitative Methodology and Cultural Psychology. In C. Willig \& W.Rogers (Eds.). The Handbook of Qualitative Methodology in Psychology. London:Sage.

Rieber, R. W. (1997) (ed.). The Collected Works of L. S. Vygotsky : The History of the Development of Higher Mental Functions, Volume IV (Marie J. Hall; Translator). New York : Plenum
Press.

Rogoff, B. (1995). Observing sociocultural activity on three planes : Participatory appropriation, guided participation, and apprenticeship. In J. V. Wertsch P. del Rio, and A. Alvarez (Eds.). Sociocultural studies of mind (pp. 139-164). Cambridge, England : Cambridge University Press.

Russell, D.R. (1997). Rethinking Genre in School and Society: An Activity Theory Analysis. Iowa State University.

Salomon, Gavriel. (1993). Distributed Cognitions. New York: Cambridge Univ. Press.

Saxe, G. B. (1994). Studying cognitive development in sociocultural context: The development of a practice-based approach. Mind, Culture, and Activity, 1 (3), 135 - 157.

Scribner, S. (1997). Mind in action : a functional approach to thinking. In E. Tobach et al. (eds.), Minds and Social Practice : Selected Writings of Sylvia Scribner (pp. 296-307). New York : Cambridge University Press.

Tharp, R.G. \& Gallimore, R. (1988). Rousing Minds to Life : Teaching, Learning and Schooling in Social Context. Cambridge: Cambridge University Press.

Valsiner, J. (1996). Cultural Organization of Cognitive Functions. In M.P. Friedman and E.C. Carterette (eds.), Handbook of Perception and Cognition ( $2^{\text {nd }}$ ed.) Vol.3 (pp. 29-58). San Diego, CA: Academic Press.

Vygotsky, L. S. (1978). Mind in society : The development of higher psychological processes (M.Cole, V. John-Steiner, S. Scribner, and E. Souberman, Eds.). Cambridge : Harvard University Press.

Wells, Gordon. (1999). Dialogic Inquiry: Toward a socio-cultural Practice and Theory of Education. NY: Cambridge Univ. Press.

Wertsch, J. V. (2000). Vygotsky's two minds on the nature of meaning. In Carol D. Lee and Peter Smagorinsky, Vygotskian Perspectives on Literacy Research : Constructing Meaning through Collaborative Inquiry (pp. 19-30). Cambridge, UK: Cambridge University Press.

Wertsch, James et al (eds.) (1995). Socio-cultural Studies of Mind. NY: Cambridge Univ. Press.

Young, M.F.D. (2008). Bringing Knowledge Back In: From Social Constructivism to Social Realism in the Sociology of Education. London: Routledge.

Gaysu R. Arvind is Senior Reader in Elementary and Social Education in Department of Education at Delhi University. She was the Post-Doctoral Commonwealth Fellow at the University of Manchester. Her works has been published in the Journal of Cultural Historical Psychology and International journal of Social Science. Department of Education 33, Chhatra Marg University of Delhi Delhi-110 00 E-mail: arvind.gaysu@vsnl.com

Institutional Context, Classroom Discourse and Children's Thinking: pedagogy re-examined

Gaysu R. Arvind

Recebido: $13 / 08 / 2008$

$1^{\text {a }}$ Revisão: $18 / 10 / 2008$

Aceite final: 18/10/2008 